\title{
Model Perencanaan Pengiriman Struktur Anjungan Lepas Pantai
}

\author{
Mohammad Idham Harari, I Gusti Ngurah Sumanta Buana, dan Achmad Mustakim \\ Departemen Teknik Transportasi Laut, Institut Teknologi Sepuluh Nopember (ITS) \\ e-mail: mustakim.achmad@gmail.com
}

\begin{abstract}
Abstrak-Anjungan atau bangunan lepas pantai (offshore platform) adalah struktur atau bangunan yang dibuat sebagai sarana dalam proses eksplorasi minyak dan gas di lepas pantai. Jenis anjungan lepas pantai yang sering dipakai di Indonesia adalah jenis fixed platform. Anjungan lepas pantai ini dibuat di darat, kemudian diangkut dan diinstalasi di lokasi eksplorasi. Pengangkutan ini biasanya menggunakan 3 (tiga) cara atau skenario yang merupakan kombinasi antara ketersediaan dan ukuran barge. Setiap cara dipilih dengan alasan yang tidak jelas selain kedua yang disebut di atas, oleh karena itu penelitian ini bertujuan untuk mengetahui faktor yang mempengaruhi pemilihan skenario pengangkutan dan pemilihan barge untuk mengangkut jacket maupun topside, dan kemudian membuatnya dalam sebuah model. Berdasarkan hasil wawancara, penentuan skenario pengiriman jacket dan topside dilakukan dengan memperhatikan 4 faktor, yaitu, (i) jadwal selesai fabrikasi dan instalasi jacket maupun topside (ii) dimensi dan berat jacket dan topside (iii) ketersediaan barge, serta (iv) jarak dari lokasi fabrikasi ke instalasi. Pembuatan model untuk memilih skenario yang tepat dilakukan setelah mewawancarai beberapa pakar di bidangnya. Berdasarkan hasil perhitungan model, pada site 1, barge yang terpilih adalah $B 34$ dengan sewa harian sebesar Rp 1.927 jt. dan barge B4 sewa TCH/bulan sebesar Rp 2.199 jt. Sedangkan barge dalam negeri yaitu B18 sewa TCH per bulan sebesar Rp 2.147 jt. dan B19 sewa harian sebesar Rp 1.023 jt. Pada site 2 barge yang terpilih adalah B14 dengan sewa VCH sebesar Rp 6309 jt. Sedangkan barge dalam negeri adalah B17 sewa tch per bulan sebesar Rp 11897 Jt. Pada site 3 barge luar negeri yang terpilih adalah barge B10 dengan sewa harian sebesar Rp 4.448 jt. dan B15 dengan sewa TCH/bulan sebersar Rp 3.302 jt. Sedangkan barge dalam negeri yaitu B20 dengan sewa VCH sebesar Rp 3.659 jt. dan B16 dengan sewa TCH per bulan sebesar 8119 jt.
\end{abstract}

Kata Kunci-Jacket, Barge, Time Charter Hire, Voyage Charter Hire.

\section{PENDAHULUAN}

I NDUSTRI heavylift cargo memiliki peran yang penting dalam mendukung kegiatan industri di berbagai sektor, seperti pada sektor minyak dan gas, industry pertambangan, industry konstruksi dan industry infrastruktur.

Indonesia memiliki komoditas yang berlimpah, diantaranya yaitu cadangan minyak bumi dan gas alam yang nantinya akan digunakan untuk bahan bakar untuk alat transportasi. Selain sumberdaya minyaknya yang banyak di Indonesia juga terdapat banyak perusahaan fabrikasi bangunan lepas pantai diantaranya PT PAL Indonesia (Surabaya), PT. McDermott Indonesia (Batam), PT Guna Nusa Fabricator (Cilegon), PT Nippon Steel Indonesia (Batam), PT Hyundai Tg. Uncang (Batam), dan PT. Saipem (Batam). Selain untuk memenuhi kebutuhan dalam negeri PT.

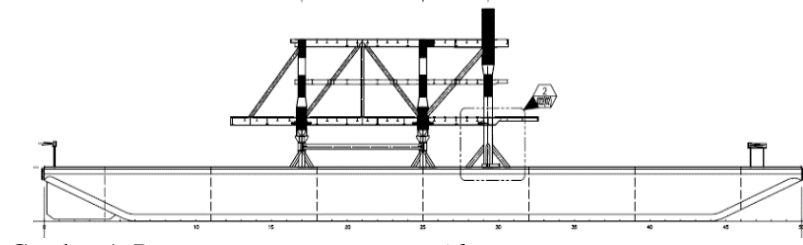

Gambar 1. Perencanaan pemuatan topside.

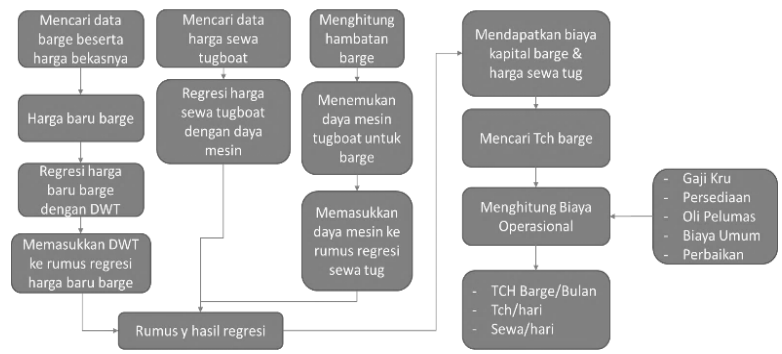

Gambar 2. Tahapan mencari biaya kapital dan sewa barge.

PAL Indoesia juga memproduksi bangunan lepas pantai untuk diekspor ke luar negeri.

Dari beberapa jenis anjungan lepas pantai, di Indonesia paling banyak adalah jenis fixed platform. Fixed platform adalah struktur anjungan lepas pantai yang terdiri dari 2 (dua) bagian utama yaitu jacket dan topside. Dalam prakteknya sesuai dengan hasil wawancara penulis dengan beberapa orang yang berkecimpung dalam bidang offshore, ada tiga skenario transportasi yang dilakukan dalam pengiriman fixed platform tersebut, yang pertama yaitu mengirimkan jacket dahulu kemudian topside dengan menggunakan satu barge yang sama untuk, yang kedua yaitu mengirimkan topside dan jacket secara bersamaan dalam satu barge. Dan yang ketiga yaitu mengirimkan topside dan jacket dengan barge yang berbeda. Kemudian pemilihan barge sebagai moda untuk mengirim fixed platform, terkadang terlalu besar dari segi dimensi jika dibandingkan dengan muatan dalam hal ini yaitu pada struktur topside seperti yang terjadi pada pengiriman salah satu topside berjenis wellhead yang dikerjakan oleh PT. PAL dengan ukuran topside dengan panjang 12.9, lebar 9.1 $\mathrm{m}$ dan berat 692.12 ton. Jarak pelayaran $64 \mathrm{~km}$ diangkut dengan menggunakan barge dengan ukuran Lpp $76.2 \mathrm{~m}$ dan lebar $24.38 \mathrm{~m}$. (Gambar 1)

Oleh karena latar belakang diatas maka maka penelitian ini dibuat bertujuan untuk mencari faktor apa yang mempengaruhi pemilihan skenario dan barge dalam pengiriman fixed platform, mengetahui alasan mengapa barge yang memiliki ukuran jauh lebih besar dari pada topside, dan mengetahui bagaimana membuat model pengiriman fixed platform, dengan memperhatikan pada pemilihan barge, jadwal instalasi dan biaya transportasi. 


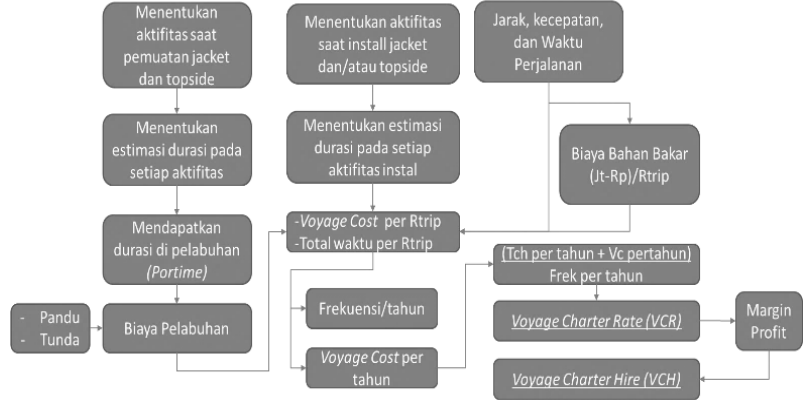

Gambar 3. Tahapan mencari voyage cost dan voyage charter hire.

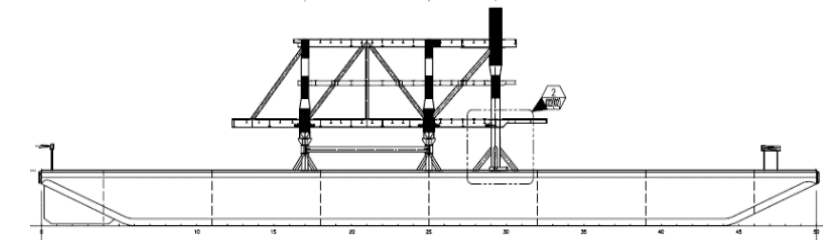

Gambar 4. Rencana pemuatan topside diatas barge.

\section{METODE PENELITIAN}

Metode pengumpulan data dalam penelitian adalah metode pengumpulan data secara langsung (primer), dan tidak langsung (sekunder). Pengumpulan data ini dilakukan dengan mengambil data terkait dengan permasalahan dalam penelitian.

Tahap pengolahan data dalam penelian ini meliputi analisis kondisi saat ini, analisis waktu pengiriman, analisa penanganan muatan, analisis biaya transportasi, pembuatan model. Pada tahap pembuatan model, dilakukan perhitungan waktu dan biaya dari masing-masing barge di masing-masing site. Gambar 2 dan 3 merupakan beberapa tahapan pengerjaan penelitian.

\section{GAMBARAN UMUM}

\section{A. Fix Platform}

Wilayah Indonesia saat ini mempunyai sekitar 60 cekungan hidrokarbon dan $73 \%$ dari seluruh cekungan tersebut terletak didaerah pantai dan laut. Dari jumlah cekungan yang memiliki lokasi di lepas pantai dan laut tersebut, sebanyak 2/3 dari jumlah tersebut berada di wilayah laut dangkal. Cekungan sedimen di Indonesia sendiri terbagi menjadi 2 wilayah yaitu wilayah Indonesia Bagian Barat (IBB) dan wilayah Indonesia Bagian Timur (IBT). Cekungan sedimen di wilayah IBB pada umumnya terletak di laut dangkal, sebaliknya di IBT cekungan hidrokarbon banyak terletak di laut dalam. Dari data sementara yang ada saat ini, di wilayah Indonesia Bagian Barat terdapat 22 cekungan hidrokarbon dimana hanya $33 \%$ berada dilaut dalam. Sedangkan di wilayah Indonesia Bagian Timur terdapat 33 cekungan hidrokarbon 42 dengan $86 \%$ berada di laut dalam dan sisanya berada di laut dangkal. Namun lebih dari $50 \%$ dari cekungan tersebut yang belum dilakukan kegiatan produksi. Dari keadaan tersebut dapat dilihat bahwa kebutuhan fasilitas penunjang untuk kegiatan produksi di laut dangkal maupun laut dalam masih banyak dibutuhkan. Untuk kegiatan produksi di laut dangkal, potensi pembangunan jacket dan topside deck memiliki potensi yang cukup besar. Sedangkan untuk daerah yang berlokasi di laut dalam,
Tabel 1.

Dimensi Topside pada Platform x,y,z

\begin{tabular}{lllll}
\hline \hline & & Keterangan & & \\
No. & Deskripsi & Topside $\mathrm{x}$ & Topside $\mathrm{y}$ & Topside $\mathrm{z}$ \\
\hline 1 & Berat Strukur & $692.12 \mathrm{ton}$ & $1500 \mathrm{ton}$ & $1000 \mathrm{ton}$ \\
2 & Jumlah Kaki & $4 \mathrm{kaki}$ & $4 \mathrm{kaki}$ & $4 \mathrm{kaki}$ \\
3 & Panjang & $12.9 \mathrm{~m}$ & $25 \mathrm{~m}$ & $20 \mathrm{~m}$ \\
4 & Lebar & $9,15 \mathrm{~m}$ & $8 \mathrm{~m}$ & $10 \mathrm{~m}$ \\
5 & Tinggi & $23.17 \mathrm{~m}$ & $20 \mathrm{~m}$ & $25 \mathrm{~m}$ \\
\hline \hline
\end{tabular}

Tabel 1.

Dimensi Jacket pada Platform x,y,z

\begin{tabular}{lllll}
\hline \multicolumn{5}{c}{ Dimensi Jacket $\mathrm{pada}$ Platform $\mathrm{x}, \mathrm{y}, \mathrm{Z}$} \\
Keterangan \\
No. & Deskripsi & Jacket $\mathrm{x}$ & Jacket $\mathrm{y}$ & Jacket $\mathrm{z}$ \\
\hline 1 & Berat Strukur & $1000 \mathrm{ton}$ & $3000 \mathrm{ton}$ & $2000 \mathrm{ton}$ \\
2 & Jumlah Kaki & $4 \mathrm{kaki}$ & $4 \mathrm{kaki}$ & $4 \mathrm{kaki}$ \\
3 & Panjang (Bag. Bawah) & $27.90 \mathrm{~m}$ & $27.90 \mathrm{~m}$ & $30 \mathrm{~m}$ \\
4 & Lebar (Bag. Bawah) & $17.61 \mathrm{~m}$ & $17.61 \mathrm{~m}$ & $20 \mathrm{~m}$ \\
5 & Tinggi (Bag. Bawah) & $60.80 \mathrm{~m}$ & $55 \mathrm{~m}$ & $70 \mathrm{~m}$ \\
6 & Panjang (Bag. Atas) & $12.90 \mathrm{~m}$ & $25 \mathrm{~m}$ & $20 \mathrm{~m}$ \\
7 & Lebar (Bag. Atas) & $9.10 \mathrm{~m}$ & $8 \mathrm{~m}$ & $10 \mathrm{~m}$ \\
\hline \hline
\end{tabular}

fasilitas produksi yaitu topside deck amat diperlukan untuk menunjang kegiatan tersebut. Dengan demikian untuk beberapa taun ke depan potensi pembangunan jacket struktur dan topside deck masih banyak dilakukan, terlebih masih banyak lokasi cekungan hidrokarbon di lepas pantai yang belum di eksplorasi [1]. Ada beberapa jenis anjungan lepas pantai yang dibuat diseluruh dunia. Diantara jenis anjungan tersebut, jenis anjungan terpancang (Fixed Platform) saat ini paling banyak digunakan di dunia, walaupun jenis ini hanya ekonomis beroperasi di perairan terbatas, yakni dengan kedalaman sekitar 400 - 500 meter saja. Sesuai dengan perairan Indonesia, yang rata-rata kedalamannya kurang dari 100 meter, maka jenis anjungan yang paling cocok digunakan adalah bangunan lepas pantai terpancang, atau fixed platform.

\section{B. Kondisi Pengiriman Anjungan Lepas Pantai}

Pada tahun 2015 Proyek pembuatan platform x telah selesai dibuat di PT. PAL dan telah dikirim ke lokasi instalasi. Proses pengiriman tersebut meliputi 2 (dua) tahap besar yaitu persiapan awal dan proses logistik.

1) Persiapan Awal

Dalam praktiknya garis besar alur bisnis proyek anjungan lepas pantai ini berawal dari pihak owner yang membuka sebuah penawaran proyek ke website mereka untuk dapat dilihat oleh para kontraktor. Kemudian pihak Fabrikasi/kontraktor mengetahui proyek tersebut, maka mereka mulai untuk menghitung untuk kebutuhan fabrikasinya dan mereka nantinya juga akan membuka tender untuk diberitahukan kepada pihak ketiga. Setelah mendapatkan persetujuan (deal) dari salah satu dari banyak pihak ketiga yang mengikuti tender, selanjutnya mengajukan tender ke owner dengan telah memiliki nilai total harga sewa yang telah disepakati dengan pihak ketiga tersebut. Namun biasanya juga bisa terjadi ada beberapa pihak diatas yang menggunakan sub kontraktor seperti contoh, pihak pelayaran dalam menjalankan tugasnya menyediakan barge bisa jadi mereka pinjam barge dari perusahaan (persewaan barge) lainnya, kemudian terkait dengan manpower atau kru dalam proses instalasi anjungan mulai dari loadout sampai dengan hook up di titik instalasi, bisa jadi tidak hanya dari satu perusahaan saja mungkin ada juga dari perusahaan lainnya. 
Tabel 2 .

Jadwal pada masing-masig site

\begin{tabular}{llll}
\hline \hline & Tanggal & & \\
Nama Aktivitas & Site 1 & Site 2 & Site 3 \\
\hline Selesai fabrikasi jacket & 24-Sep-15 & 01-Jan-15 & 02-Mar-15 \\
Selesai intalasi jacket & 22-Oct-15 & 01-Feb-15 & 10-Apr-15 \\
Selesai fabrikasi topside & 03-Oct-15 & 28-Dec-14 & 11-Apr-15 \\
Selesai Instalasi topside & 30-Oct-15 & 11-Feb-15 & 19-Apr-15 \\
\hline \hline
\end{tabular}

Tabel 3 .

Spesifikasi barge Maritime Eagle

\begin{tabular}{|c|c|c|}
\hline No. & Nama Barge & Maritime Eagle \\
\hline 1 & Bendera & Indonesia \\
\hline 2 & Tahun & 2003 \\
\hline 3 & Panjang & $250 \mathrm{ft}(76.2 \mathrm{~m})$ \\
\hline 4 & Lebar & $80 \mathrm{ft}(24.38)$ \\
\hline 5 & Tinggi & $16 \mathrm{ft}(4.88 \mathrm{~m})$ \\
\hline 6 & Draft & $13 \mathrm{ft}(3.91 \mathrm{~m})$ \\
\hline 7 & Dwt & 5400 ton \\
\hline 8 & Deck Load & $15 \mathrm{ton} / \mathrm{m} 2$ \\
\hline
\end{tabular}

Bisnis fabrikasi atau pembuatan anjungan lepas pantai, merupakan salah satu dari banyak cabang bidang usaha yang bergerak di bidang minyak dan gas (migas). Dalam usaha ini ada 3 pihak utama yang saling bekerjasama dalam mengerjakan suatu proyek, pihak-pihak tersebut adalah owner yaitu pemilik anjungan lepas pantai, kemudian ada pihak fabrikasi atau kontraktor yaitu pihak yang membuat bangunan lepas pantai sesuai dengan permintaan owner, dan pihak penyedia jasa instalasi anjungan lepas pantai yang pada umumnya berlaku sebagi pihak ketiga dalam suatu proyek. Penjelasan tiga pihak tersebut adalah sebagai berikut :

a. Pihak Owner/Pemilik/Perusahaan Pertambangan atau Perminyakan. Adalah pihak yang dengan kata sederhana dikatakan sebagai pemilik dari anjungan lepas pantai tersebut atau pihak yang memesan untuk dibuatkan anjungan lepas pantai, juga bisa sebagai yang megoperasikan anjungan lepas pantai tersebut.

b. Pihak Fabrikasi/kontraktor. Adalah pihak yang menerima request atau requirement dari pihak perusahaan pertambangan untuk dibuatkan anjungan lepas pantai atau dengan kata lain pihak pembuat anjungan lepas pantai. Tak hanya itu pihak fabrikasi ini juga bertugas untuk melakukan tes barang yang telah mereka buat terkait dengan bekerja atau tidaknya anjungan lepas pantai tersebut. Dan juga bertugas saat melakukan loadout anjungan lepas pantai dari dermaga ke barge, tak hanya itu juga bertugas melakukan seafastening saat sebelum perjalanan menuju site.

c. Pihak Penyedia jasa instalasi anjungan lepas pantai. Adalah pihak yang bertugas sebagai perencana dalam hal pemilihan barge dan skenario transportasi yang akan dilakukan dalam proses instalasi anjungan lepas pantai. Penelitian ini menggunakan sudut pandang dari pihak ini. Tentunya dengan pertimbangan-pertimbangan yang ada seperti jadwal instalasi dan kondisi perairan yang meliputi kecepatan angin dan tinggi gelombang, selain perencanaan skenario transportasi pihak ini biasanya juga menawarakan pekerjaannya sampai proses instalasi, mereka menyediakan fasilitas-fasilitas seperti barge, crane barge dan juga alat piling. Tanggung jawab pihak ketiga ini dimulai saat barge berlayar dari tempat fabrikasi sampai proses instalasi.

Setelah mendapatkan klien pekerjaan pihak ketiga ini barulah memulai pekerjaannya yang diawali dari mencari barge, dalam mencari barge yang dibutuhkan waktu selama
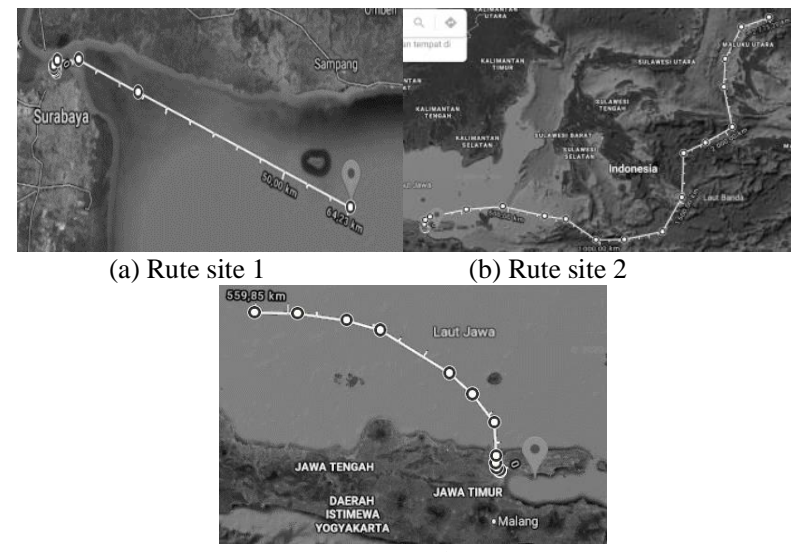

(a) Rute site 1

Gambar 4. Rute site

kurang lebih 3 minggu, setelah menemukan barge yang cocok pada saat itu juga akan dilakukan pemesanan atau booking yang disertai dengan kegiatan penjelasan pekerjaan dan negosiasi, proses ini membutuhkan waktu kurang lebih selama 1 minggu. Kemudian proses persiapan berkas-berkas kontrak yang dilakukan pemilik barge maupun penyewa kegiatan ini membutuhkan waktu kurang lebih 1 minggu.

Proyek pembuatan Wellhead Platform x diawali oleh PT. PAL yang memenangkan tender oleh Husky-CNOOC Madura Ltd. (HCML) untuk mengerjakan proyek ini. Platform yang dikerjakan adalah platform untuk pengeboran sumur gas alam yang disebut dengan Wellhead Platform yang strukturnya bertipe fixed platform, terdiri dari 2 bangunan utama yaitu jacket dan topside. Dalam mengerjakan proyek ini PT. PAL bekerjasama dengan pihak ketiga yang bertugas seperti yang telah dijelaskan sebelumnnya. Pengiriman dimulai dari pabrik pembuatan anjungan yaitu PT. PAL Indonesia yang berada di Kota Surabaya hingga titik instalasi ditengah laut yang telah ditentukan, yaitu di lepas pantai di Selat Madura Jawa Timur, sekitar $65 \mathrm{~km}$ sebelah timur Surabaya dan sekitar $16 \mathrm{~km}$ selatan Pulau Madura. Jenis layanan pengiriman yang dipakai dalam proyek Platform $\mathrm{x}$ ini tidak ada, karena setiap proses dalam keseluruhan proses intalasi dikerjakan oleh perusahaan yang berbeda, dalam proses loadout dikerjakan oleh perusahaan ALE, proses instalasi yang meliputi jasa pengiriman jalur laut dan jasa instalasi berupa tenaga kerja dan crane barge dikerjakan oleh perusahaan PT. Salam Bahagia.

Namun jika memakai sudut pandang forwarder maka layanan yang digunakan adalah door to door. Door to door dimana PT. PAL merupakan tempat produksi sekaligus titik asal dari pengiriman, dan titik instalasi adalah sebagai titik tujuan dari pengriman. Biaya yang muncul adalah biaya saat proses memuat anjungan dari tempat produksi menuju ke dermaga diteruskan sampai muatan terangkut diatas barge atau (proses loadout), dilanjutkan proses pengiriman pada jalur laut, dan proses instalasi.

Adapun biaya-biaya yang ditangguhkan untuk keseluruhan kegiatan saat proses loadout hingga instalasi di site, diantaranya adalah

a. Biaya pemuatan meliputi biaya transportasi dari lapangan fabrikasi ke dermaga dan dari dermaga pemuatan ke atas barge.

b. Biaya transportasi laut dari PT. PAL hingga titik instalasi.

c. Biaya instalasi di titik instalasi.

Dimana semakin lama waktu yang dibutuhkan dalam prosesnya maka akan semakin banyak biaya yang akan 


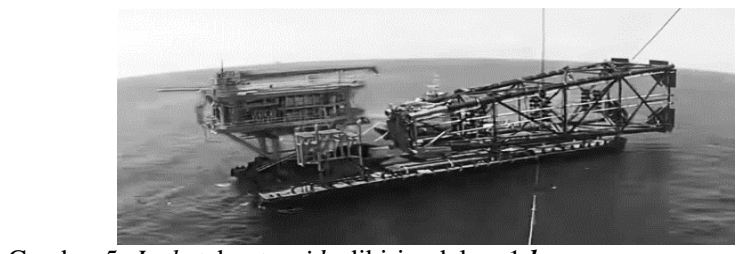

Gambar 5. Jacket dan topside dikirim dalam 1 barge

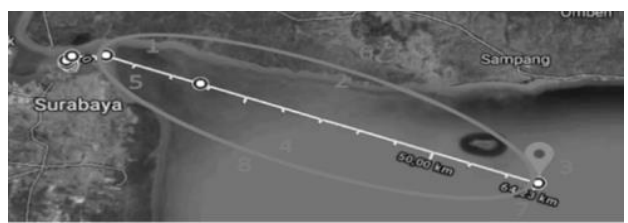

Gambar 6. Ilustrasi Skenario transportasi pada skenario 1.

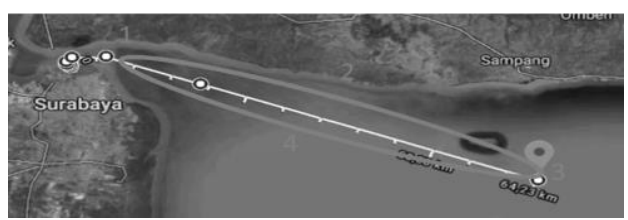

Gambar 7. Ilustrasi Skenario transportasi pada skenario 2.

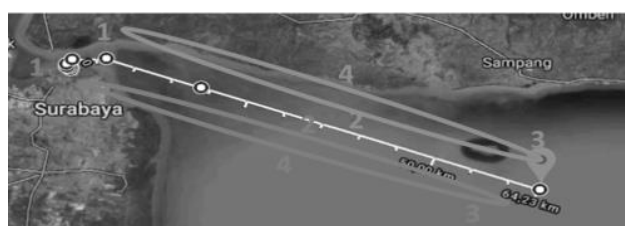

Gambar 8. Ilustrasi Skenario transportasi pada skenario 3.

dikeluarkan. Setelah penentuan komponen utama perhitungan yang telah disesuaikan dengan permintaan pemilik barang yaitu PT. PAL, maka tahapan selanjutnya adalah mendefinisikan ruang lingkup pekerjaan sebagai bahan utama perencanaan biaya dan perencanaan operasi. Untuk kegiatan transportasi dari lapangan fabrikasi sampai proses muat keatas barge bekerja sama dengan perusahaan bongkar muat untuk mengerjakan hal tersebut. Dasar pemilihan perusahaan bongkar muat berdasarkan pertimbangan terhadap kesediaan fasilitas yang memadai dan pengalaman perusahaan bongkar muat dalam menangani heavylift kargo seperti anjungan lepas pantai. Untuk menjamin perjalanan selama proses perngiriman dari resiko kecelakaan dan kerusakan selama pengiriman, maka pendaftaran asuransi dilakukan, dikarenakan nilai barang, maka jenis asuransi yang diambil adalah All Risk Insurance, artinya seluruh proses dari pengiriman tersebut di asuransikan untuk seluruh kemungkinan resiko yang terjadi.

\section{2) Proses Logistik}

Logistik merupakan peroses perencanaan, pelaksanaan,dan pengendalian aliran yang effisien dan efektif mulai dari titik asal sampai titik tujuan untuk memenuhi kebutuhan permintaan costumer. Pada sub bab ini akan dibahas satu per satu komponen utama logistik untuk pengiriman struktur anjungan lepas pantai $\mathrm{X}$ dari fabrikasi PT. PAL ke titik instalasi pada tahun 2015. Berikut ini merupakan proses logistik dalam pengiriman anjungan lepas pantai.

3) Storage, warehousing, and materials handling

a. Location of warehouse

Dalam penelitian ini gudang yang digunakan sebagai gudang penyimpanan jacket maupun topside yaitu berada pada gudang produksi PT. PAL yang berada di Ujung Surabaya Jawa Timur, Indonesia.

b. Number and size of distribution depots
Tabel 4

Rinician aktivitas dan asumsi durasi aktivitas pemuatan

\begin{tabular}{lll}
\hline \hline Aktifitas & Durasi & Satuan \\
\hline Barge port in & 2 & jam \\
Mooring & 0.17 & jam/tali \\
Gas free check & 0.01667 & jam/GT \\
Barge joint inspection & 0.25 & jam/meter \\
Barge handover & 2 & jam \\
Barge pre ballasting & 2 & jam \\
Loadout jacket to barge & 5 & meter/jam \\
Initial seafasting & 0.5 & jam/titik \\
Towing ballast & 2 & jam \\
Complete seafastening & 0.5 & jam/titik \\
Inspection by mws & 0.17 & jam/m2 \\
Casting off mooring line and barge & 0.17 & jam/tali \\
handover & & \\
\hline \hline
\end{tabular}

Tabel 5.

Rincian aktivitas dan asumsi durasi aktivitas instalasi jacket

\begin{tabular}{lll}
\hline \hline Aktivitas & Durasi & \\
\hline Launching jacket & 0.00056 & jam/meter \\
Upending jacket & 1 & jam \\
Pilling jacket & 0.20 & jam/meter/pile \\
Remove sefastening & 0.5 & jam/titik \\
\hline \hline
\end{tabular}

Tabel 6 .

Rincian aktivitas dan asumsi durasi aktivitas instalasi topside

\begin{tabular}{lll}
\hline \hline Aktivitas & Durasi & \\
\hline Remove sefastening & 0.5 & jam/titik \\
Lifting topside & 1 & jam \\
Install topside & 2 & jam/kaki \\
Completion & 5.00 & jam \\
Final inspection & 2.00 & jam \\
\hline \hline
\end{tabular}

Tempat fabrikasi anjungan lepas pantai dalam PT. PAL terletak pada area divisi rekayasa umum yang di desain khusus untuk kegiatan yang berkatian dengan heavylift cargo. Oleh karena itu beberapa fasilitas memiliki kapasitas yang besar seperti kekuatan dermaga 10 ribu ton. kedalaman kolam dermaga $-15 \mathrm{~m}$ dan juga luas dermaga seluas $2000 \mathrm{~m}^{2}$

c. Type of storage

Storage (penyimpanan), lokasi penympanan untuk anjungan lepas pantai $\mathrm{X}$ ini terletak di tempat produksi yaitu PT. PAL Surabaya.

\section{d. Metrial Handling Equipment}

Anjungan lepas pantai yang merupakan jenis muatan heavylift cargo, membutuhkan penanganan khusus yang berbeda daripada muatan lainnya. Adapun beberapa peralatan penanganan yang disiapkan yang dibagi menjadi dua titik yaitu dermaga PT. PAL dan lokasi instalasi.

Setelah anjungan lepas pantai melewati tahap percoban yaitu mekanik tes dan elektrik tes, maka selanjutnya akan dilakukan proses persiapan spmt untuk mengangkut struktur dengan desain dan perhitungan-perhitungan yang telah dilakukan terkait dengan jumlah spmt dan titik-titik tumpuan, setelah siap maka spmt akan menuju tempat produksi untuk kemudian mengangkat dan mengantarkannya sampai masuk ke dalam barge dan meletakkannya pada penyanggapenyangga (support) yang telah terlebih dahulu dipasang pada barge. Selama pemuatan (loadout), ballast barge harus terus-menerus disesuaikan untuk mempertahankan draft dan trim yang sesuai dengan operasi pemuatan. Kekakuan barge dan muatannya mungkin sangat berbeda sehingga mengakibatkan defleksi, yang dapat menyebabkan tekanan tinggi pada struktur mana pun. Analisis tegangan rinci biasanya diperlukan baik dari struktur dan barge untuk fase pemuatan dan transportasi.

Berikutnya adalah proses pengikatan atau kegiatan seafastening, yaitu kegiatan mengikat struktur pada barge 
Tabel 9.

Total hari pemakaian barge pada masing-masing site

\begin{tabular}{llll}
\hline \hline Kode Barge & Site 1 & Site 2 & Site 3 \\
\hline b1 & 32.42 & 76.52 & 45.00 \\
b4 & 34.09 & 78.18 & 46.67 \\
b10 & 35.53 & 79.62 & 48.11 \\
b13 & 39.30 & 83.39 & 51.88 \\
b14 & 37.96 & 82.05 & 50.53 \\
b15 & 38.69 & 82.78 & 51.26 \\
b21 & 32.02 & 76.12 & 44.60 \\
b27 & 32.42 & 76.52 & 45.00 \\
b30 & 34.13 & 78.22 & 46.71 \\
b34 & 33.89 & 77.98 & 46.46 \\
\hline \hline
\end{tabular}

Tabel 10.

Hasil perhitungan time charter hire $(\mathrm{TCH})$

\begin{tabular}{lllll}
\hline \hline Kode barge & Lpp $(\mathrm{m})$ & $\mathrm{B}(\mathrm{m})$ & Tch/hari & sewa / hari \\
\hline b1 & 55 & 21.34 & 83 & 91 \\
b4 & 75 & 23.5 & 72 & 79 \\
b10 & 84 & 23.5 & 88 & 97 \\
b13 & 92 & 30.755 & 145 & 159 \\
b14 & 120 & 35 & 130 & 143 \\
b15 & 122 & 36.6 & 150 & 166 \\
b21 & 65 & 15.03 & 24 & 26 \\
b27 & 55 & 21.34 & 83 & 91 \\
b30 & 70 & 24.4 & 110 & 121 \\
\hline \hline
\end{tabular}

dengan pasak-pasak atau braket yang telah di las di dek barge, kegiatan ini bertujuan untuk sebagai pengamanan muatan agar struktur diatas barge tidak dapat bergoyang saat barge mengalami goyangan (Gambar 4). Setelah seafastening maka barge akan melakukan perjalanan menuju site. Sesampainya di lokasi instalasi maka akan dilakukan proses offload atau proses dimana muatan anjungan lepas pantai yang ada di atas barge di turunkan atau lepaskan dari barge. Setelah struktur anjungan lepas pantai sampai di site maka dilakukan pelepasan braket-braket yang telah dipasang pada saat akan berangkat, untuk kemudian dilakukan tahap berikutnya. Disini ada dua proses launching atau penanganan yang berbeda antara jacket dengan topside.

4) Information and control

a. Design of system

Adapun beberapa hal yang diperhatikan dalam merencanakan sebuah sistem pengiriman. Penting untuk mendapatkan gambaran yang jelas pada muatan termasuk spesifikasinya. Husky-CNOOC Madura Ltd. Memesan offshore platform berjenis fixed platform, terdiri dari dua bangunan utama yaitu jacket dan topside. Berikut ini dimensi dari jacket dan topside $\mathrm{x}$.

Anjungan lepas pantai tidak memiliki dimensi yang baku, bermacam-macam ukuran dan berat karena pembuata anjungan lepas pantai di pengaruhi oleh keadaan alam dimana anjungan tersebut akan diinstal, keadaan alam seperti tinggi gelombang, kecepatan angin, dan kedalaman perairan. Pengiriman dilakukan pada tanggal 10 oktober 2015 untuk jacket dan 17 oktober untuk topside. Pengiriman jacket dan topside ini tepat waktu karena tidak melebihi jadwal install yang telah ditentukan oleh owner, yaitu pada tanggal 22 oktober untuk jacket dan 30 oktober untuk topside.

Berat dan volume jacket dan topside menjadi pertimbangan utama untuk menentukan moda ukuran barge yang akan digunakan, selain untuk menentukan ukuran barge juga akan mempengaruhi pekerjaan handlingnya terkait dengan spmt saat loadout dan crane barge yang akan digunakan. Dimensi dari platform ini juga terdiri dari dua dimensi yaitu dimensi topside dan jacket. Untuk dimensi topside kaki sisi
Tabel 7.

Hasil perhitungan harga sewa per bulan

\begin{tabular}{llll}
\hline \hline Kode barge & Lpp $(\mathrm{m})$ & $\mathrm{B}(\mathrm{m})$ & Tch/bulan \\
\hline b1 & 55 & 21.34 & 2490 \\
b4 & 75 & 23.5 & 2152 \\
b10 & 84 & 23.5 & 2641 \\
b13 & 92 & 30.755 & 4347 \\
b14 & 120 & 35 & 3894 \\
b15 & 122 & 36.6 & 4514 \\
b21 & 65 & 15.03 & 707 \\
b27 & 55 & 21.34 & 2490 \\
b30 & 70 & 24.4 & 3299 \\
\hline \hline
\end{tabular}

Tabel 8

Biaya Pelayaran disetiap site

\begin{tabular}{llll}
\hline \hline Kode Barge & Site 1 & Site 2 & Site 3 \\
\hline b1 & 86 & 4543 & 910 \\
b4 & 47 & 2446 & 490 \\
b10 & 49 & 2535 & 508 \\
b13 & 151 & 7981 & 1598 \\
b14 & 40 & 2014 & 405 \\
b15 & 41 & 2080 & 418 \\
b21 & 13 & 606 & 122 \\
b27 & 86 & 4543 & 910 \\
b30 & 83 & 4360 & 873 \\
b34 & 53 & 2785 & 558 \\
\hline \hline
\end{tabular}

atas diberi jarak 40 kaki $(12,19 \mathrm{~m})$ untuk sisi bagian TimurBarat dan 30 kaki $(9,15$ m) untuk sisi bagian Utara-Selatan.

Untuk lebih jelasnya dapat dilihat pada Tabel 1.

Dimensi Topside pada Platform x,y,z. Pada penelitian ini platform $\mathrm{x}$ menjadi contoh anjungan lepas pantai yang akan dikirim, yang kemudian penulis juga menambahkan 2 (dua) anjungan lepas pantai dengan tipe yang sama yaitu platform y, dan platform $\mathrm{z}$ dengan spesifikasi yang berbeda, jadwal, dan jarak dari PT. PAL hingga titik instalasi yang berbeda agar dapat mengetahui pengaruh dari ketiga hal tersebut dalam pemilihan skenario dan pemilihan barge. (Tabel 1-3)

\section{b. Control Procedures}

Suatu pengiriman baik ekspor impor maupun domestik setiap aktivitas memiliki kontrol dari masing-masing bagian dari suatu organisasi yang sudah dibentuk. Selain struktur organisasi adapun beberapa contoh dokumen yang dapat berfungsi sebagai controlling pergerakan barang, salah satunya yaitu Bill of Lading, merupakan surat tanda terima barang yang telah dimuat di dalam barge yang juga merupakan tanda bukti kepemilikan barang serta bukti adanya kontrak atau perjanjian pengangkutan barang melalui laut.

5) Transport

a. Mode of transport

Dalam penanganan anjungan lepas pantai transportasi digunakan pada saat proses loadout dan pada proses pengiriman jalur laut, pada proses loadout proyek $\mathrm{x}$ ini menggunakan spmt digunakan untuk memindahkan anjungan lepas pantai yang sudah jadi dari lapangan produksi sampai menuju barge. Batasan kondisi alam seperti kekuatan jalan dan jembatan yang secara langsung dapat mempengaruhi kemampuan dari perjalanan spmt, sehingga diperlukan informasi distribusi beban diseluruh titik pada spmt. Total beban yang diterima oleh spmt dapat menentukan kebutuhan dari panjang spmt.

Sedangkan untuk moda angkutan laut dalam proyek Platform $\mathrm{x}$ ini menggunakan armada barge yang disewa dari perusahaan penyedia jasa persewaan barge PT. Salam Bahagia. Perusahaan ini bertempat di Jakarta Barat. Barge 
Tabel 11.

Hasil perhitungan vch

\begin{tabular}{llll}
\multicolumn{4}{c}{ Hasil perhitungan vch } \\
\hline Kode barge & VCH (Jt-Rp) & & \\
\hline b1 & 5795 & Site 2 & site 3 \\
b4 & 4987 & 70017 & 4590 \\
b10 & 6218 & 8194 & 3661 \\
b13 & 11316 & 18141 & 8623 \\
b14 & 9355 & 10315 & 6309 \\
b15 & 10949 & 11736 & 7316 \\
b21 & 1559 & 2062 & 1123 \\
b27 & 5795 & 10017 & 4590 \\
b30 & 7716 & 11499 & 5770 \\
b34 & 4400 & 6872 & 3347 \\
\hline \hline
\end{tabular}

yang digunakan yaitu barge maritime eagle. Untuk spesifikasinya ditunjukkan pada Tabel 4.

b. Type of delivery

Syarat pengiriman yang digunakan yaitu door to port, artinya pengiriman dilakukan dari gudang produksi yaitu PT. PAL sampai ke titik instalasi di laut. Gambar 5 merupakan rute di masing-masing site.

6) Load Planning

a. Rute Transportasi Loadout

Rute pengangkutan platform $\mathrm{x}$ dari tempat produksi hingga dermaga untuk loadout, kemudian dilanjutkan rute dari dermaga PT. PAL sampai menuju lokasi instalasi yang berupa titik koordinat yaitu Lintang Utara $7^{\circ} 22^{\prime} 20.09^{\prime \prime}$ LU dan Bujur Timur $113^{\circ} 16^{\prime} 36.44^{\prime \prime}$ BT dengan jarak pelayaran sejauh $28 \mathrm{~nm}$.

b. Cargo handling dari gudang produksi menuju dermaga

Dari gudang produksi sampai menuju dermaga, jacket dan topside yang ditaruh diatas support (semacam dudukan) berupa besi baja kemudian diangkat oleh sistem hydraulic dari spmt, sehingga beban dari jacket ataupun topside akan berpindah ke spmt, sebelum proses ini tentnya sudah melalui desain dan perhitungan yang matang.

c. Penentuan lokasi muat dan temporary storage

Lokasi muat dan temporary storage untuk stuktur anjungan lepas pantai secara umum berada di tempat produksi atau tempat pembuatan struktur tersebut dibangun.

d. Perencaan permuatan ke atas barge di PT. PAL

Untuk pemuatan keatas barge, persiapan yang dilakukan bergantung pada dengan metode apa loadout dilakukan, dalam proyek x ini loadout menggunakan spmt yang artinya persiapan akan sedikit lebih sederhana dibandingkan dengan menggunakan metode skidding atau metode lifting (pengangkatan dengan crane).

e. Perencanaan operasi barge

Perencanaan operasi barge pada pengiriman anjungan lepas pantai bergantung pada jadwal instlasinya. Pada umumnya skema transportasi untuk anjungan lepas pantai fixed platform yaitu dengan mengangkut jacket beserta pilepile atau pipa-pipa besi penegar dari fabrikasi terlebih dahulu dengan satu barge dipakai untuk angkut jacket dan topside secara bergantian, seperti yang dilakukan pada saat pengiriman fixed platform $x$ untuk dikirim ke Madura. Dengan urutan pekerjaan diawali dari pengantaran jacket dari fabrikasi menuju site, setelah sampai site maka jacket akan diturunkan (offload) dari barge yang kemudian akan diinstal dengan bantuan crane barge yang telah melakukan persiapan-persiapannya. Kemudian setelah proses instalasi selesai barge dan tug boat dapat kembali menuju tempat fabrikasi untuk melakukan loadout lagi mengambil topside, kemudian setelah topside terangkut dengan sempurna, barge barge akan berjalan menuju site, dan sesampainya di site maka crane barge akan membantu dalam proses instalasi topside.

Namun ada beberapa kondisi dimana skema yang digunakan dalam transportasi offshore berbeda seperti pada umumnya, karena terkait dengan pengaruh dari faktor-faktor yang telah disebutkan. Beberapa kasus yang pernah terjadi seperti pada proyek yang dalam skema transportasinya yaitu dengan satu barge yang dapat mengangkut jacket dan topside sekaligus. Salah satu kasusnya yaitu dimana Boa Barge 29 terlibat dalam transportasi laut Borkum Riffgrund I Offshore (BRK01) dan mengangkut jacket, topside, dan 8 pile, penulis menganggap skema ini sebagai skema kedua. (Gambar 6)

Tidak hanya skema diatas yang dapat terjadi dilapangan, namun juga ada kemungkinan lainnya seperti skema kedua dengan urutan yang dimulai dari barge mengangkut jacket dari tempat fabrikasi menuju site, dan topside dengan menggunakan dua barge yang berbeda dengan jadwal keberangkatan yang berbeda dengan selisih waktu yang disesuaikan dengan jadwal.

7) Perencanaan bongkar di lokasi instalasi

Dalam kasus pengiriman anjungan lepas pantai pembongkaran jacket ataupun topside akan dibantu oleh crane barge. Crane barge dapat membantu pengangkatan jacket dan mendirikan jacket hingga posisi vertikal dan siap untuk di instal, atau dengan menggunakan metode launching dimana metode ini memanfaatkan berat dari jacket itu sendiri dan kemiringan barge yang sengaja diatur sampai jacket dapat tergelincir kedalam air, kemudian pengangkatan topside juga dibantu oleh crane barge.

\section{ANALISA DAN PEMBAHASAN}

\section{A. Skenario Pengiriman Anjungan Lepas Pantai}

Seperti yang telah disebutkan pada latar belakang penelitian ini, bahwa ada 3 (tiga) skenario yang dilakukan dalam pengiriman struktur anjungan lepas pantai berjenis fixed platform. Berikut ini merupakan penjelasan dari masing-masing skenario

\section{1) Skenario Pertama}

Sekenario pertama merupakan mengangkut jacket, pile dan topside dengan menggunakan barge yang sama secara bergantian, yaitu mengangkut jacket terlebih dahulu kemudian mengangkut topside. Gambar 7 merupakan ilustrasi dan runtutan aktivitas pada skenario yang pertama

Berikut merupakan keterangan nomor urutan kegiatan dalam skenario pertama:

a. Setelah proses pemuatan jacket dan pile, Barge berangkat menuju site

b. Barge menempuh perjalanan mengantar jacket

c. Barge menunggu install jacket

d. Barge kembali ke PT PAL untuk mengambil topside

e. Melakukan pemuatan topside

f. Barge menempuh perjalanan mengantar topside

g. Barge menunggu instal topside

h. Barge kembali menuju PT PAL

2) Skenario Kedua

Skenario kedua merupakan skenario dengan mengangkut jacket,pile dan topside secara bersamaan dengan menggunakan 1 (satu) barge, sehingga pengangkutan hanya dilakukan 1 (satu) kali saja. Gambar 8 merupakan ilustrasi dan penjelasan runtutan kegiatan pada skenario 2 (dua)

Berikut merupakan keterangan nomor urutan kegiatan dalam skenario kedua: 
Tabel 12.

Pemilihan skenario pada setiap site

\begin{tabular}{lll}
\hline \hline Site 1 & Site 2 & Site 3 \\
\hline 3 & 2 & 3 \\
\hline \hline
\end{tabular}

1. Setelah proses pemuatan jacket, pile dan topside, Barge berangkat menuju site

2. Barge menempuh perjalanan mengantar jacket, pile dan topside

3. Barge menunggu install jacket dan topside

4. Barge kembali ke PT PAL

3) Skenario Ketiga

Skenario ketiga merupakan skenario dengan mengangkut jacket, pile dan topside dengan menggunakan 2 (dua) barge yang berbeda. Gambar 8 merupakan ilustrasi dan runtutan aktivitas pada skenario yang ketiga.

Berikut ini merupakan keterangan nomor urutan kegiatan dalam skenario yang ketiga. Untuk kegiatan pada barge pertama yaitu:

a. A) Pemuatan jacket dan pile

b. A) Barge mengirim jacket ke site

c. A) Instalasi jacket

d. A) Barge kembali ke PT PAL

Sedangkan untuk kegiatan pada barge kedua yaitu:

a. B) Pemuatan topside

b. B) Barge mengirim topside ke site

c. B) Instalasi jacket

d. B) Barge kembali ke PT PAL

Skenario-skenario diatas memiliki perbedaan waktu dalam pengerjaannya, mulai dari pemuatan (port time), waktu saat pengiriman (sea time) dan waktu saat instalasi. Maka dari itu setelah mengetahui ilustrasi skenario, akan dilakukan perhitungan waktu.

Dalam perhitungan waktu, sebelumnya penulis memakai rincian aktivitas mulai dari pemuatan hingga instalasi anjungan yang didapat dari pencarian data sekunder dan kemudian juga membuat asumsi terkait dengan durasi pada setiap kegiatan yang ada, beberapa asumsi ini didapatkan dari hasil wawancara penulis dengan orang yang yang berkecimpung dalam bidang anjungan lepas pantai, Tabel 5 merupakan asumsi tersebut :

Selanjutnya yaitu asumsi waktu instalasi jacket yang ditunjukkan pada Tabel 6 .

Selanjutnya yaitu asusmsi waktu instalasi topside yang ditunjukkan pada Tabel 7.

Setelah mengetahui durasi dari setiap aktivitas, selanjutnya melakukan perhitungan waktu di setiap alternatif barge jika digunakan pada masing-masing site. Tabel 8 merupakan hasil dari penggunaan barge di setiap site.

Setelah dihitung total hari pemakaian barge maka akan dihitung biaya kapital per tahun dari masing-masing barge yang kemudian dari biaya kapital tersebut akan ditemukan harga sewa per hari, per bulan, dan voyage charter hire (vch) dari barge tersebut. Seperti yang tertera pada Tabel 10-11.

Setelah ditemukan harga sewa per hari dan per bulan maka akan dilakukan perhitungan biaya pelayaran pada masingmasing site sehingga dapat ditemukan voyage charter hire.

Dari hasil voyage cost diatas maka akan didapatkan voyage cost hire (vch). Dengan mengetahui Tch per tahun dan frekuensi pada rute per tahun maka akan didapat vyage cost per tahun yang kemudian dibagi dengan jumlah frekuensi per tahun maka akan menghasilkan voyage cost rate ( $\mathrm{ver}$ ) dan ditambahkan profit sebesar $10 \%$ maka akan menghasilkan vch.
Tabel 12 merupakan hasil perhitungan vch pada masingmasing site dan masing-masing barge. Selanjutnya akan dilakukan pemilihan barge dengan menggunakan formula yang telah dibuat pada masing masing skenario, dan menghasilkan pemilihan skenario sebagai berikut:

Formula yang dibuat dalam menentukan skenario pada setiap site adalah:

1. Skenario 2 terpilih jika : rentang jadwal instalasi jacket dan topside lebih $<=$ waktu trip saat mengangkut + waktu pemuatan jacket dan topside + waktu instalasi jacket dan topside, serta jadwal selesai fabrikasi topside $<=$ jadwal selesai fabrikasi jacket

2. Skenario 3 terpilih atas 3 kondisi :

a. Ketika rentang jadwal instalasi jacket dan topside >= waktu seatime Rtrip + waktu pemuatan jacket + waktu instalasi jacket dan ketika jadwal selesai fabrikasi topside $>=$ jadwal instalasi jacket

b. Ketika rentang jadwal instalasi jacket dan topside $<=$ waktu seatime Rtrip + waktu pemuatan jacket + waktu instalasi jacket dan jadwal selesai fabrikasi topside <= jadwal instalasi jacket

c. Ketika rentang jadwal instalasi jacket dan topside $<=$ waktu seatime Rtrip + waktu pemuatan jacket + waktu instalasi jacket dan jadwal selesai fabrikasi topside >= jadwal instalasi Jacket

3. Skenario 1 terpilih ketika: rentang jadwal instalasi jacket dan topside >= waktu rtrip + waktu pemuatan jacket dan topside + waktu instalasi jacket dan topside serta jadwal selesai fabrikasi topside $<=$ jadwal selesai instalasi jacket

Dari pemilihan skenario yang telah dilakukan (Tabel 12) maka didapatkan hasil:

a. Pada site 1 barge yang terpilih adalah dan barge B 34 sewa harian sebesar Rp $1927 \mathrm{Jt}$ dan barge B4 sewa Tch/Bulan sebersar Rp 2199 Jt Sedangkan barge dalam negeri yaitu B18 sewa tch per bulan sebesar Rp $2147 \mathrm{Jt}$ dan B19 sewa harian sebesar Rp $1023 \mathrm{Jt}$

b. Pada site 2 barge yang terpilih adalah barge B14 sewa VCH sebesar Rp 6309 Jt. Sedangkan barge dalam negeri yaitu B17 sewa tch per bulan sebesar Rp 11897 Jt

c. Pada site 3 barge luar negeri yang terpilih adalah barge B10 sewa harian sebesar Rp 4448 Jt dan B15 sewa Tch/Bulan sebersar Rp 3302 Jt. Sedangkan barge dalam negeri yaitu B20 sewa vch sebesar Rp 3659 Jt dan B16 sewa tch per bulan sebesar Rp $8119 \mathrm{Jt}$

\section{KESIMPULAN}

Dari penelitian yang telah dilakukan maka dapat diperoleh kesimpulan sebagai berikut:

1. Faktor apa yang mempengaruhi pemilihan skenario transportasi dalam pengiriman fixed platform

a. Jadwal Selesai Fabrikasi dan Jadwal Selesai Instalasi jacket dan topside.

b. Ukuran dimensi dan berat jacket dan topside

c. Ketersediaan barge (ukuran \& kapasitas)

d. Jarak dari tempat fabrikasi menuju site

2. Jadwal dan ketersediaan barge dengan variasi ukuran yang sedikit mengakibatkan pengiriman topside sering menggunakan barge dengan ukuran yang jauh lebih besar dari topside.

3. Pemilihan barge tetap mencari yang paling murah dari alternatif barge yang tersedia, walaupun ukurannya jauh lebih besar dari pada jacket atau topside 
4. Pemilihan Barge

a. Pada site 1 dengan ukuran panjang jacket $60.88 \mathrm{~m}$, lebar $17.6 \mathrm{~m}$ dan berat 1000 ton dan topside dengan panjang 12.9 , lebar $9.1 \mathrm{~m}$ dan berat 692.12 ton. Jarak pelayaran $64 \mathrm{~km}$ dengan jadwal selesai fabrikasi jacket 24 Sep 15, selesai instalasi jacket 22 okt 15, selesai fabrikasi topside 3 okt 15 dan selesai instalasi topside 30 okt 15 . maka skenario yang tepilih adalah skenario 3 barge yang terpilih adalah dan barge $\mathrm{B} 34$ dengan spesifikasi $\mathrm{Lpp}=76.20 \mathrm{~m}$ dan $\mathrm{B}=24.38 \mathrm{~m}$ untuk antar topside dengan term sewa harian sebesar $\mathrm{Rp} 1927 \mathrm{Rp}$ dan barge B4 dengan spesifikasi Lpp=75 $\mathrm{m}$ dan $\mathrm{B}=23.50 \mathrm{~m}$ untuk antar topside dengan term sewa Tch/Bulan sebersar Rp 2199 Jt. Sedangkan barge dalam negeri yaitu B18 dengan spesifikasi $\mathrm{Lpp}=76.20 \mathrm{~m}$ dan $\mathrm{B}=24.38 \mathrm{~m}$ untuk antar jacket dengan term sewa tch per bulan sebesar Rp $2147 \mathrm{Jt}$ dan $\mathrm{B} 19$ dengan spesifikasi $\mathrm{Lpp}=76.20 \mathrm{~m}$ dan $\mathrm{B}=$ $24.38 \mathrm{~m}$ untuk antar topside dengan term sewa harian sebesar Rp $1023 \mathrm{Jt}$

b. Pada site 2 dengan ukuran panjang jacket $55 \mathrm{~m}$, lebar $17.6 \mathrm{~m}$ dan berat 3000 ton. Dan topside dengan panjang $25 \mathrm{~m}$, lebar 8 , dan berat 1500 ton. Jarak pelayaran $2700 \mathrm{~km}$ dengan jadwal selesai fabrikasi jacket 1 jan 15 , selesai instalais jacket 1 feb 15 , selesai fabrikasi topside 28 dec 14 dan selesai instalasi topside 11 feb 15. Maka skenario yang terpilih adalah skenario 2 barge yang terpilih adalah barge B14 dengan spesifikasi $\mathrm{Lpp}=120 \mathrm{~m}$ dan $\mathrm{B}=35 \mathrm{~m}$ dengan term sewa VCH sebesar Rp 6309 Jt. Sedangkan barge dalam negeri yaitu B17 dengan spesifikasi Lpp=
$100.58 \mathrm{~m}$ dan $\mathrm{B}=36.58 \mathrm{~m}$ untuk antar topside dengan term sewa tch per bulan sebesar Rp $11897 \mathrm{Jt}$

c. Pada site 3 dengan ukuran ukuran panjang jacket 70 $\mathrm{m}$, lebar $20 \mathrm{~m}$ dan berat 2000 ton dan topside dengan panjang $20 \mathrm{~m}$, lebar $10 \mathrm{~m}$ dan berat 1000 ton. Jarak pelayaran $560 \mathrm{~km}$ dengan jadwal selesai fabrikasi jacket 2 Mar 15, selesai instalasi jacket 10 apr 15, selesai fabrikasi topside 11 apr 15 dan selesai instalasi topside 19 april 15. Maka skenario yang tepilih adalah skenario 3 barge luar negeri yang terpilih adalah barge $\mathrm{B} 10$ dengan spesifikasi $\mathrm{Lpp}=84 \mathrm{~m}$ dan $\mathrm{B}=23.50$ $\mathrm{m}$ untuk antar jacket dengan term sewa harian sebesar Rp 4448 Jt dan B15 dengan spesifikasi Lpp=122 m dan $\mathrm{B}=36.60 \mathrm{~m}$ untuk antar topside dengan term sewa Tch/Bulan sebersar Rp 3302 Jt. Sedangkan barge dalam negeri yaitu B20 dengan spesifikasi Lpp $=76.20$ $\mathrm{m}$ dan $\mathrm{B}=24,38 \mathrm{~m}$ untuk antar jacket dengan term sewa vch sebesar Rp $3659 \mathrm{Jt}$ dan B16 dengan spesifikasi $\mathrm{Lpp}=100.58 \mathrm{~m}$ dan $\mathrm{B}=36.58 \mathrm{~m}$ untuk antar topside dengan term sewa tch per bulan sebesar Rp $8119 \mathrm{Jt}$

\section{UCAPAN TERIMA KASIH}

Penulis mengucapkan terimakasih kepada pihak yang telah membantu proses penelitian ini. Kepada PT. PAL Indonesia, serta instansi-instansi yang terkait atas semua bantuan dan dukungan yang diberikan terkait penyelesaian penelitian ini.

\section{DAFTAR PUSTAKA}

[1] F. Putra, "Analisa teknis dan ekonomis pembangunan industr manufaktur bangunan lepas pantai di Jawa Timur," Surabaya, 2016. 